\title{
ИНТЕРТЕКСТУАЛЬНЫЙ АНАЛИЗ: ПРИНЦИПЫ И ГРАНИЦЫ \\ (Хроника конференции в Санкт-Петербургском государственном университете, 2I-22 апреля 2016 года)
}

\author{
Ф. Н. Двинятин \\ (С.-Петербург) \\ С. О. Леоненко \\ (Беркли / С.-Петербург)
}

Своего рода «второе рождение» - удел многих филологических дисциплин: то, чем, казалось бы, занимались всегда, с появлением некоторых ключевых работ достигает принципиально новой полноты и точности, окончательно оформляясь в особую область и/или метод исследования. Так было с русским стиховедением после появления первых статей Андрея Белого, с нарратологией после «Discours du récit» Жерара Женетта, с исследованием поэтической грамматики после работ Романа Якобсона. В этом году (или в следующем: научные перевороты трудно датировать с совершенной точностью) можно отметить полувековой юбилей одного из подходов, преобразивших нашу науку. Хотя поиск и упорядочение «параллельных» и «общих мест» - одна из древнейших основ (наряду с описанием метрических схем, толкованием темных мест ключевого для данной культуры текста, первыми опытами составления грамматик и словарей) протофилологического и собственно филологического анализа, хотя задачи академического комментария всегда требовали обращения к поиску цитат, заимствований и общих мест, все же именно работы пятидесятилетней давности положили начало осознанию межтекстового анализа как одного из основных разделов и методов поэтики и филологии вообще. Одни прежде всего назовут здесь 
первые публикации К. Ф. Тарановского, посвященные вскрытию и толкованию подтекстов мандельштамовских стихотворений, почти сразу поддержанные ахматоведческими наблюдениями Т. В. Цивьян и В. Н. Топорова, работами О. Ронена, 3. Г. Минц, Р. Д. Тименчика, Г. А. Левинтона, и чуть позже - А. К. Жолковского, Б. М. Гаспарова, И. П. Смирнова, М. Л. Гаспарова и их коллег; для других основной вехой будет «Bakhtine, le mot, le dialogue et le roman» Юлии Кристевой, где был введен ключевой термин «интертекстуальность». Как бы то ни было, полстолетия прошло. Двадцать лет тому назад «конец цитаты» был констатирован М. В. Безродным в полигенетическом («конец Ренаты», «конец прекрасной эпохи», «смерть автора» и др.) названии его книги. «Девальвационные процессы», чутко подмеченные В. Н. Топоровым применительно к другой, некогда модной области исследования (поиску анаграмм), вполне сказались и в области интертекстуальных штудий. В российском литературоведении (где, в отличие от французской и американской традиций, осознание огромной роли межтекстовых связей не привело к катастрофическому переходу к постструктурализму, а стало одним из направлений обогащения и расширения структурной и семиотической поэтики) общий принцип поиска интертекстуальных соответствий объединяет авторов, ориентирующихся на традиционные историко-литературные подходы, на формальный и структурный анализ, на цивилизованно постструктуралистские прочтения; однако - наряду с влиятельными и новаторскими работами - он используется и в тысячах вполне проходных и неубедительных исследований. Можно если не оправдать, то понять тот скепсис, который иногда вызывают уже не только несовершенства и преувеличения отдельных гипотез, но и сам подход как таковой.

На кафедре истории русской литературы СПбГУ работает научный семинар «Интертекстуальный анализ: принципы и границы» (руководитель - профессор А. Д. Степанов). Его участники выступили инициаторами проведения международного семинара под тем же названием, для участия в котором были приглашены преподаватели кафедры, ее давние научные партнеры, многие 
классики интертекстуальных исследований в области русистики и общей теории литературы. Не все званые смогли принять участие в семинаре, но и с учетом некоторых лакун состав докладчиков оказался более чем представительным. Пожалуй, столь широкий круг признанных специалистов впервые был объединен в рамках конференции с четко сформулированной теоретической программой - по крайней мере, за многие последние годы. Предлагая «идеологию» семинара, организаторы обращались к гостям с предложением ответить на вопросы о границах между верифицируемыми и необязательными межтекстовыми параллелями, о применимости понятий «топика» и «топос» к литературе Нового времени, о современном состоянии и перспективах «мифопоэтического» анализа - то есть о самой общей теоретической программе, способной объединить исследователей интертекстуальных связей из разных школ и направлений. Участники поразному отозвались на эту преамбулу. Одни использовали ее как теоретическую рамку различных case studies, которые, по их эксплицитному или имплицитному мнению, составляют тело интертекстуальных исследований; другие поделились теоретическими и/или полемическими размышлениями. Тех и других объединяло близкое понимание целей и принципов филологического, историколитературного, поэтического исследования, знание истории интертекстуальных изысканий, их идеологического контекста и современного, во многом кризисного, состояния.

Открывавший первое пленарное заседание П. Е. Бухаркин (СПбГУ) начал с тезиса о том, что уже давно не открывающая новых теоретических горизонтов интертекстуальная проблематика чрезвычайно свойственна литературе эпохи готового слова. Однако в риторической словесности непрерывное заимствование никогда не преследует цели диалога с претекстом. Воспринимаемый как образец совершенства формы, к которому следует стремиться, он становится всеобщим достоянием, и цитация происходит уже не из конкретного текста-источника, но из некоего «общекультурного резервуара». Таким образом, по вполне резонному замечанию докладчика, здесь уместнее говорить о топике (в классической 
терминологии Курциуса), а не о «мозаике цитат» в духе Кристевой или Барта. Отметим, что для целого ряда участников именно критика постструктуралистского понимания ключевого термина конференции становилась поводом для общетеоретического пессимизма.

Ф. Н. Двинятин (СПбГУ) в своем докладе «Поэтическая традиция - топика - интертекстуальность» предложил последовательно различать три явления, названия которых вынесены в заглавие сообщения, как своего рода три концентрических круга: разовые, сильные межтекстовые связи (доказанные либо предполагаемые); топика, понимаемая в целом в духе Курциуса, и примыкающая к ней по большинству показателей микротопика формульности; поэтическая традиция как особым образом организованный язык поэзии, - межтекстовый, межличностный, диктующий поэту некоторые стандартные ассоциации, и в то же время в практике каждого поэта непрерывно видоизменяемый, развивающийся и как будто создающийся заново. Особое внимание в докладе было уделено поэтической традиции и взаимодействию всех типов межтекстовых связей - в первую очередь, тем случаям, где отдельные межтекстовые связи осложнены и дополнены развитием большой поэтической традиции (грамматический род слова чинар/чинара и глагольный вид в ремарках отвечал/ответил, кольцовский пятисложник в квазицитате Горького из Берга/Нефедова, динамика глагольных времен в русской лирике, поэтические перечисления благовоний и др.). Обосновывалось также предложенное соавторами этого обзора (в развитие идей В. Н. Топорова) понятие «интертекстуального поля» особого типа контекстов, делающих весьма вероятным наличие в данном месте сильных межтекстовых связей, топики либо явлений круга поэтической традиции.

Ю. Б. Орлицкий (РГГУ) выступил с докладом «К вопросу об интертекстуальном потенциале редких стиховых форм в русской поэзии: античных (гекзаметр и логаэд) и восточных (хайку, рубаи)». На материале русской лирики XX века было показано, как метрическая и строфическая форма «подсказывает» современному автору, какие смыслы и ассоциации заложены в ней имманентно. При этом авторы могут либо полностью опираться на принятый 
в национальной традиции смысловой ореол конкретной стиховой формы, тем самым поддерживая его, либо вступать с традицией в более или менее конструктивный диалог. Основным материалом доклада послужила новейшая история русского гекзаметра (Стратановский, Шварц, Дашевский, Амелин и др.), в качестве дополнительных примеров привлекались опыты аналогичного использования различных логаэдических форм, так или иначе соотносимых с античной топикой и тематикой, а также нерифмованных трехстиший (русских хайку) и рубаи, отсылающих к дальневосточной и среднеазиатской экзотике соответственно.

М. Н. Виролайнен (ИРЛИ РАН, СПбГУ) в докладе «Поэтическая география как интертекст» вновь обратилась к собственной концепции словесной культуры Золотого века как периода особого отношения между словом и денотатом. Виролайнен показала, что топонимы в литературе Золотого Века не обозначают объекты в реальной географии - их появление в тексте всегда обусловлено уже сложившимся поэтическим словарем эпохи. С некоторыми оговорками (жанр дружеского послания) можно сказать, что связь между топонимом и географическим местом полностью разрывается, и топоним получает метонимическое («брега Невы» - Петербург) или эмблематическое (Новгород - свобода) значение. В случаях первого появления нового географического понятия в поэтическом тексте авторы либо апеллируют к уже существующей связи локуса с поэтической традицией (ссыльный Пушкин влачит «мрачны дни» подобно Овидию, по наблюдению Б. М. Гаспарова, воспринимая вслед ему данный локус в том числе и как северный), либо включают его в устоявшуюся поэтическую формулу. Входя в стихотворный текст, географическое название становится словом поэтического языка, а географический локус - поэтическим топосом.

В. М. Паперный (Университет Хайфы) начал сообщение «Интертексты Льва Толстого (к проблеме различения адресованной и неадресованной интертекстуальности)»с теоретических замечаний. Адресованная интертекстуальность предполагает знание читателем претекстов, что обеспечивает более глубокое и полное понимание нового текста, вступающего с ними во взаимодействие. 
При неадресованной интертекстуальности, напротив, связь с текстами-источниками не важна, поскольку новый текст переписывает (причем как в эпигонском, так и в блумовском смысле) или вовсе отменяет их. Именно эту мощную редакторскую интенцию докладчик акцентировал в поэтике Толстого. Манипулятивная интертекстуальность, образчиком которой, по мысли Паперного, может быть борхесовский Пьер Менар, лежит в основе толстовского «Соединения и перевода четырех евангелий», где автор разрабатывает изощренную процедуру превращения чужого текста в «свой».

Выступление И. Н. Сухих (СПбГУ) «О границах интертекста (Чеховский текст и “интертекст")» носило характер методологического напутствия. По мнению докладчика, инструментальным ключевой термин конференции становится лишь в том случае, если признается свойством лишь некоторых авторов и произведений (ср. «цитатных» и «нецитатных» поэтов в трактовке В. Л. Маркова). Необходимо описать градацию интертекстуальных совпадений, тогда связь нескольких текстов может рассматриваться как слабая или сильная валентность. И только во втором случае интертекст становится инструментом в интерпретации данного текста. Доклад иллюстрировался, главным образом, примерами из А. П. Чехова.

В докладе А. Д. Степанова (СПбГУ) «Чехов и Баранцевич: К вопросу о критериях интертекста» был поставлен вопрос о сочетании «внешних», историко-литературных (обстоятельства работы над текстом Чехова и история его печатных выступлений о Баранцевиче) и «внутренних», структурных критериев (совпадение актантной структуры «субъект - предикат - объект»), позволяющих связать тексты, соотнесенность которых не зафиксирована документально. При анализе рассказов А. П. Чехова «Супруга» (1895) и К. С. Баранцевича «Котел» (1888) докладчик показал, что знакомство Чехова с текстом Баранцевича было весьма вероятно, убедительно объяснив возможный мотив обращения к сходному сюжету. Чехов, критиковавший своего коллегу за «неколоритность» стиля, в рассказе «Супруга» продемонстрировал, как добиться яркости в трактовке стертой и заезженной темы. 
Секционное заседание конференции, посвященное интермедиальности, было открыто сообщением О. Славиной (Гамбургский университет) «Русско-немецкая арабеска: Интертекстуальность визуального у В. А. Жуковского». Акварель немецкого художника Герхардта фон Рейтерна 1831 г. была рассмотрена в докладе как в рамках романтического представления об арабеске, сформулированного Гёте и потому в обсуждаемый период широко известного, так и в соотношении с биографическими реалиями (дружеские и творческие связи с В. А. Жуковским) и актуальной для художника идеей романтического жизнетворчества. Делая наброски фронтисписа для своего собрания сочинений, Жуковский создает эскиз, напоминающий композицию акварели Рейтерна. Так арабеска становится каналом трансляции интермедиальности в эпоху романтизма.

В докладе С. Д. Титаренко (СПбГУ) «Интертекстуальность vs. интермедиальность в поэтике символистов: Стратегии репрезентации» был рассмотрен особый тип внутритекстовых взаимосвязей в художественном произведении, основанный на взаимодействии кодов различных искусств. Образ в поэтике символистов - событие внутреннего опыта, а не просто «мимесис реальности»: его основой может послужить и интертекст (имя, цитата, реминисценция), и интермедиальный образ (картина или впечатление от нее, музыка или музыкальный мотив, памятник архитектуры). Докладчица обратилась к итальянским стихотворениям Блока, в которых экфрасисы объединяются с отсылками к поэтическим текстам Данте, Петрарки и Пушкина. Художественные коды литературы и других искусств, входя в символистский текст, оказываются в ситуации взаимообогащения, и в этом смысле интермедиальность поэтики символизма сопротивляется интерпретации с точки зрения постструктуралистской теории интертекстуальности.

Проблеме взаимодействия искусств у символистов было посвящено и выступление Н. Ю. Грякаловой (ИРЛИ РАН) «От экфрасиса к интертексту. Вокруг стихотворения Вяч. Иванова “Нарцисс. Помпейская бронза”». Стихотворение 1904 г. из сборника 
«Прозрачность» представляет собой экфрастическое описание скульптуры из коллекции помпейской бронзы Национального археологического музея в Неаполе. Вопреки определенности заглавия экфразируемый образ выстраивается принципиально неоднозначно, представляя одновременно Нарцисса и Диониса, что находит источник в истории искусствоведческой рецепции артефакта. Бронзовая скульптура юноши, найденная в Помпеях в 1862 г. и приобретшая эпохальную известность как «Нарцисс», в ходе искусствоведческих дискуссий получила другую атрибуцию «Дионис» и вошла в специальную литературу под обозначением «Дионис (так называемый Нарцисс)». Таким образом, созданный Ивановым оригинальный вариант экфрасиса был инспирирован в том числе и ситуацией атрибутивной неопределенности артефакта.

Завершившая заседание секции Л. Д. Бугаева (СПбГУ) обратилась к феномену аудиовизуальной метафоры. Интертекстуальные операции и механизм метафоризации были рассмотрены на примере романа Виктора Пелевина “S.N.U.F.F." (2011), ориентированного, среди прочего, на «китайскую комнату» Дж. Серла и научно-фантастический роман канадского писателя Питера Уоттса "Blindsight" (2006). Аудиовизуальная метафора, по Бугаевой, предполагает когнитивный эксперимент, осуществляющийся в сознании читателя/зрителя и требующий проведения ментальных операций по распознаванию пространств в их концептуальном смешении в литературном или кинотексте.

Секцию «Интертекст в поэтическом тексте» открыл Е. М. Матвеев (ИЛИ РАН, СПбГУ). Сообщение «Интертекстуальность как риторическая доминанта: Стихотворение Георгия Иванова “Свободен путь под Фермопилами...”» содержало риторический анализ текста знаменитого ивановского центона. В стихотворении были выявлены различные способы включения чужого слова: ритмическая цитата, перекличка риторических доминант (ивановский текст и блоковская «Незнакомка», его главный претекст, имеют общую риторическую доминанту - антитезу), цитата в узком смысле, аллюзии и реминисценции различных типов. 
В докладе «Горацианский центон М. Н. Муравьева: Стихотворение “К Хемницеру”» Р. Л. Шмараков (НИУ ВШЭ, С.-Петербург) представил анализ рецепции горациевской поэзии в юношеском стихотворении М. Н. Муравьева. Начиная стихотворение 1776 года «К Хемницеру» интертекстуальной работой с одой Горация «К Помпею Гросфу», далее Муравьев сменяет модель, обращаясь уже к материалу вергилиевых «Георгик». Смена ориентира дает возможность корректировать один классический авторитет другим. Особо примечательно, что за пределами своего текста Муравьев оставляет появляющиеся и у Горация, и у Вергилия приамели перечни альтернатив, кульминацией которых является выбор самого поэта. На уровне тематики же Муравьев отказывается от горацианской концепции жизни здесь и сейчас в пользу устремленности в будущее.

С. И. Монахов (СПбГУ) в докладе «“Осенняя воля” А. А. Блока: Еще раз к вопросу о подражательном потенциале ритмической структуры стихотворного текста» говорил о необходимости скорректировать подход к изучению проблемы семантического ореола размера. «Осенняя воля» Блока была выбрана для анализа как представитель традиции использования пятистопного хорея, с исследования которой начинал К. Ф. Тарановский. По мнению докладчика, уязвимость концепции Тарановского заключалась в том, что тот исключил из рассмотрения ритмику исследуемых текстов, в то время как подражательный потенциал стихотворной речи наиболее естественным образом должен реализовываться именно на этом уровне. Из множества текстов, характеризующихся общностью стихотворного размера, комплекса мотивов и синтаксических формул, докладчик предложил выделить подкорпус текстов, в которых эти совпадения носят не случайный, а ритмически обусловленный характер.

Ряд докладов был выполнен в жанре интертекстуального комментария, и два из них касались пушкинской эпохи. Е. В. Кардаш (ИРЛИ) в докладе «Стихотворение А. С. Пушкина "Из А. Шенье”: Перевод как интертекстуальная проблема» обратилась к вольному переводу Пушкиным идиллии А.-М. де Шенье «CEta, mont ennobli 
par cette nuit ardent...» («Эта, гора, облагороженная той пылающей ночью...») из однотомника 1819 года. Среди произведений, на которые предположительно мог ориентироваться Пушкин, были названы французские переводы «Метаморфоз» Овидия, «Приключения Телемака» Фенелона и либретто Ж.-Ф. Мармонтеля к опере Антуана Доверня «Умирающий Геркулес» (1761). Помимо этого, пушкинский текст обнаруживает образные и мотивные отсылки к другим произведениям Шенье из указанного сборника (идиллии «Слепец» и элегии XXXV «Hier, en te quittant, enivré de tes charmes...» - «Вчера, когда я шел, тобою упоенный...»), а также автореминисценции, указывающие на связь перевода «Из А. Шенье» с замыслом стихотворения «Не дай мне бог сойти с ума...». По замечанию докладчицы, ни одна из аллюзий в отдельности не может рассматриваться как безусловная; между тем, взятые вместе, они вступают во взаимодействие и подтверждают друг друга, образуя сложно устроенное интертекстуальное пространство.

В докладе А. А. Карпова (СПбГУ) «Интертекстуальное поле “классической повести” В. Ф. Одоевского “Жизнь и похождения одного из здешних обывателей в стеклянной банке, или Новый Жоко"» был выявлен ряд новых источников сборника «Пестрые сказки». Докладчик продемонстрировал, что, помимо прямо названных автором историй Эдипа и Энея, «Поэтического искусства» Буало и повести французского писателя Пужана «Жоко, анекдот, извлеченный из неизданных писем об инстинкте животных», Одоевским были использованы приемы, образы, ситуации сочинений Гофмана («Золотой горшок»), Свифта («Путешествие в Бробдингнег»), Вольтера («Микромегас»). Особенно значимой стала группа разножанровых претекстов, объединенных темой голода, входящая в роман Метьюрина «Мельмот Скиталец» история двух влюбленных, чувство которых оказалось побеждено инстинктом самосохранения, эсхатологическое стихотворение Байрона «Тьма», описания естественнонаучных экспериментов над паукообразными, а также «Опыт о законе народонаселения» Мальтуса. Используя метафору «пауков в банке», Одоевский гротескно обнажает суть мальтузианских представлений о животной природе человека, 
разрабатывая свой сюжет в духе «неистовой словесности» с ее редукционистским представлением о человеке и характерной поэтикой «ужасного» (Жюль Жанен и др.).

Сообщение Е. А. Филонова было посвящено проблеме топики в литературе постриторической эпохи. Предметом доклада стала романтическая формула/топос «морщины на челе», появляющаяся в составе портретной характеристики героя в русской поэзии и прозе первой трети XIX века. У поэтов элегической школы эта формула получает устойчивое значение: морщины - печать всеуносящего времени, след отрицательно оцениваемых утрат; в рамках «байронической» традиции формируется другой смысл: ранние морщины - признак «отмеченности», знак мистического опыта, возвышающего героя над остальными. В литературе постромантической эпохи формула продолжает функционировать, сохраняя и модифицируя эти значения. Смыслы, восходящие к жанровому мировоззрению унылой элегии, получают дополнительный обертон: морщины - символ напрасно растраченной жизни, утрата не оправдавшихся надежд юности (например, у С. Я. Надсона, И. З. Сурикова и др.). Значение, восходящее к байронической традиции, особым образом преломляется в портретных характеристиках «героя из народа», где морщины оказываются знаком специфического жизненного опыта, недоступного повествователю-интеллигенту и возвышающего этого героя - не над остальными (как у романтиков), но до остальных. Подобные примеры, по справедливому замечанию докладчика, обнаруживают актуальность топики как одной из форм интертекстуальных отношений в литературе Нового времени.

Е. Д. Толстая (Еврейский университет, Иерусалим) обратилась к генезису венецианского эпизода в романе Тургенева «Накануне». Тургенев воспроизводит стереотипы венецианского мифа, сложившегося в позднеромантическую эпоху: среди его претекстов «Паломничество Чайльд-Гарольда» Байрона, «Консуэло» Жорж Санд и, возможно, «Камни Венеции» Джона Рескина. Однако мотивно и лексически ближайшим источником тургеневской Венеции (географически неожиданно) оказывается гоголевский «Рим». 
Будучи недоволен засильем «натурализма», Тургенев мог таким образом переосмыслять художественные возможности поэтики романтизма.

В докладе Б. В. Аверина (СПбГУ) «Голоса европейских философов в "Войне и мире"» речь шла о сюжетной структуре романа о духовном становлении главных героев, их переходе от неверия к вере. Проанализировав сюжетные линии, связанные с главными героями (Пьером, Андреем, Наташей, княжной Марьей) и их духовным становлением, докладчик показал, как Толстой вводит в роман философские подтексты (от Франциска Ассизского и Фомы Кемпийского до Канта и Гегеля). В реплике на этот доклад М. Н. Виролайнен остроумно отметила, что в толстовской религиозной философии необычайно, на первый взгляд, позитивная идея единства оказывается реализуема только через небытие и смерть.

И. Э. Васильева (СПбГУ) в докладе «О крокодилах, барышнях и сумеречной действительности (к вопросу о границах интертекста)» на примере произведений Батюшкова, Лермонтова и Достоевского показала, как заимствованное из «Аталы» Шатобриана сравнение неизбежного разочарования с таящимся на дне водоема крокодилом варьируется в зависимости от контекста. Образ приобретает коннотации, обуславливающие возможность соотнесения с первоначально не входившими в его смысловое поле функционально-семантическим вариантами - с аллегорическим и фольклорно-смеховым образами крокодила. Формальный характер интертекстуальной отсылки был продемонстрирован на примере выражения «тургеневская девушка». В массовом и биографическом нарративе второй половины XX в. оно оказывается связанным не столько с женскими образами И. С. Тургенева, сколько с поведенческим стереотипом, утверждаемым дидактическим и идеологическим дискурсом. Тезис о столь позднем закреплении хрестоматийной формулы вызвал бурную дискуссию.

А. М. Грачева (ИРЛИ РАН) в докладе «Повесть А. М. Ремизова “Странница" (грани интертекстуального анализа)» продемонстрировала, что одно из наиболее герметических произведений писателя следует целому ряду до сих пор не отмеченных источ- 
ников: Библии, древнерусским оригинальным и переводным апокрифическим памятникам (апокалипсисы, видения, хождения), житиям, посланиям и даже посвященным их описанию и исследованию трудам медиевистов XIX-XX вв. Интертекст в повести «Странница» осуществляет ряд функций. Прежде всего - в условиях большевистской цензуры он дает возможность адекватно выразить историософские взгляды писателя и его политическую позицию. Также активизируется огромный пласт эсхатологических претекстов, придающих истории хождения по мукам героини эмблематический характер.

М. В. Рождественская (СПбГУ) выступила с докладом «“Жена бела" и “Жена румяна" (об одном общем фрагменте в древнерусских апокрифических текстах)». Был рассмотрен сюжет, появляющийся в ряде апокрифов («Сказание о 12 пятницах», «Беседы трех святителей», «Сказание от евангельских чудес»), сохранившихся в списках XV-XVI вв. Таким образом, данные тексты не просто основываются на общем источнике; превращаясь в своего рода топос, образ двух жен находит свое отражение и в позднейшей литературе (примером здесь послужил «Разговор с Анакреоном» М. В. Ломоносова). Стоит отметить, что история топоса со сходным лексическим наполнением (полная, белая, румяная) в литературе Нового времени была прослежена в докладе Ф. Н. Двинятина.

Н. С. Демкова (СПбГУ) в докладе «Отражение одного из мотивов “Слова о полку Игореве” в романе Бориса Пастернака “Доктор Живаго” п предположила, что в рассказе о бегстве заглавного героя из лагеря партизан Пастернак переосмысляет мотив бегства князя Игоря из половецкого плена, акцентировав прежде всего любовную линию: среди прочего, обращаясь к рябине, напомнившей ему о Ларе, Юрий Живаго называет ее княгиней. Таким образом, как показывает Н. С. Демкова, Пастернак вступает в интертекстуальный диалог с «плачем Ярославны».

М. Я. Вайскопф (Еврейский университет, Иерусалим) представил фрагмент из готовящейся к печати книги о Бабеле. Докладчик говорил о сюжетных мистификациях, объединенных общим принципом скрытого нарушения пространственно-временных и 
каузальных связей (здесь Бабель наследует Гоголю). Приведенный материал охватывает тему «посмертного существования» в рассказе «В подвале», монтаж взаимоудаленных географических и бытовых реалий в «Истории моей голубятни», параллельное время в «Конце богадельни» и всевозможные логические курьезы, иронически собранные писателем в новелле 1924 года «Ты проморгал, капитан!».

Роберт Ходель (Гамбургский университет) в докладе «“Опосредованная интертекстуальность”? (А. Платонов и упрек в “каратаевщине”)» предложил способ верификации межтекстовых связей: интертексты могут выявляться (или же «вчитываться») такими литературными институтами, как публика и критика. Упреки Платонова в «каратаевщине» являются для Ходеля весомыми аргументами для поиска у писателя толстовского интертекста, несмотря на отсутствие прямых цитат. Впрочем, в теоретической преамбуле докладчик высказал сомнение в возможности полноценной верификации интертекстуальных связей, вспомнив в этой связи термин Витгенштейна «семейное сходство».

Ю. В. Доманский (РГГУ) в докладе «Эпическое событие в лирическом сюжете (рассказ Чехова “Тоска” и стихотворение Евгения Карасёва “Бессилье”)» обратился к случаю, когда интертекстуальная связь устанавливается через границы литературных родов (лирика эпос). Основанием для сопоставления текстов Чехова и Карасёва становится тождественная ситуация - в обоих случаях человек стремится рассказать сокровенное любому, кто готов слушать. Однако эпос и лирика в этом отношении проявляют себя различно: рассказ Чехова представляет внешнее происшествие, через которое возникает возможность показать заглавное состояние персонажа. Стихотворение Карасёва же делает событием саму рефлексию субъекта, оказавшегося в состоянии бессилия.

Сообщение А. И. Жеребина (РГПУ) было посвящено функциям русского интертекста в новелле Т. Манна «Тонио Крегер». Действительно, логично предположить, что за тезисом о «святой русской литературе» должен просматриваться и русский интертекстуальный фон. Докладчик указал на то, что сам образ русской классической 
литературы формировался у Манна под влиянием русского романа (прежде всего - романов Мережковского), а история заглавного героя - опыт реализации теургической программы (русской по преимуществу). В обсуждении доклада Б. М. Гаспаров отметил, что слова о «святой русской литературе» могут быть парафразой гимна «святому немецкому искусству» в финале «Нюрнбергских мейстерзингеров» Вагнера. Ю. В. Доманский также усомнился в наличии у этой новеллы Манна русских подтекстов. В теоретическом послесловии А. И. Жеребин, как и многие другие участники семинара, говорил о сомнительности перспектив теории интертекста: модернистская по духу, идея вечного соприсутствия текстов друг в друге сегодня воспринимается в ряду концепций «вечного возвращения» Ницше, палимпсеста человеческой психики Фрейда и «большого времени» Бахтина.

Б. М. Гаспаров (Колумбийский университет, Нью-Йорк; НИУ ВШЭ, С.-Петербург) в докладе «Потомство Ницше в ХХ веке: Роман Айн Рэнд “Источник” между социалистическим реализмом и маккартистской Америкой» выявил примечательные параллели между написанным в 1943 году романом Рэнд “The Fountainhead” и поэтикой соцреализма. В центре повествования - идеологический конфликт между героем-новатором, архитектором Говардом Рорком и историком искусства Элсвортом Тухи. Рорк проповедует крайний индивидуализм сильной личности в выражениях, почти дословно взятых из Ницше. Его антагонист, напротив, исповедует коллективизм и сострадание к ближнему, в котором угадывается наследие толстовства и Владимира Соловьева. Уехавшую из СССР в 20-летнем возрасте Алису Розенбаум вряд ли можно заподозрить в сочувствии к идеалам коллективизма. Однако делая своего героя бескомпромиссным фанатиком утопической идеи, она парадоксальным образом сообщает ему черты героев социалистического реализма. Таким образом, по Б. Гаспарову, роман Рэнд выявляет родство ницшеанства, в особенности в том популистском воплощении, какое оно получило у Горького («На дне») и в революционной идеологии начала века, с советским моральным и эстетическим каноном. 
Конференцию завершил Г. А. Левинтон (Европейский университет, С.-Петербург) докладом «К истории и терминологии “интертекстуальных” исследований (1960-е - 1970-е годы)». На правах представителя классической «школы подтекстов» (К. Ф. Тарановский, О. Ронен, 3. Г. Минц, Т. В. Цивьян, В. Н. Топоров, Р. Д. Тименчик, Е. А. Тоддес) докладчик рассмотрел - историографически и мемуарно - начальный период ее становления, контекст и терминологию. Справедливо отметив ложность и непродуктивность связи интертекстуальной проблематики исключительно с постструктуралистской и постмодернистской парадигмой, Г. А. Левинтон указал на ряд актуальных для Тарановского и его школы источников: устное мандельштамоведение и эмигрантская критика (П. М. Бицилли и др.), ОПОЯЗ, отчасти Бахтин. Новация Тарановского состояла в выведении проблемы цитирования из области генезиса в область семантической мотивации. Докладчик напомнил и о своем известном функциональном разграничении «цитаты» и «заимствования», которые также различаются именно влиянием на семантику цитирующего текста. Весьма ценна «мемуарная» ремарка: Левинтон заметил, что воспринимал занятия цитацией как нечто внеположное структурализму (и скорее продолжающее ОПОЯЗовскую традицию) - в то время как для Тарановского это было вполне структуралистским упражнением. В заключение докладчик в очередной раз призвал отказаться от самого понятия «интертекст» в пользу терминологии остзейской (острота М. Л. Гаспарова) «школы подтекстов» как более строгой и учитывающей направление цитации, а постструктуралистские интертекстуальные штудии сравнил с марровскими этимологиями, которые, по выражению В. Н. Топорова, плохи тем, что слишком легкие.

Позволив себе некоторое преувеличивающее обобщение, отметим, что все участники чтений явно или неявно опирались на одну (или несколько одновременно) из следующих теоретических программ: традиционную, восходящую к поэтической практике и теоретической рефлексии доромантической эпохи (поэтики и риторики, манифесты, полемики и разборы, автокомментарии и т. д.); академическую историко-литературную, вершина 
которой - комментирование текстов XIX века, отдельные заметки об источниках и фронтальные сопоставления текстов этого времени; формалистскую и структуралистскую (работы В. В. Виноградова, В. М. Жирмунского, Б. В. Томашевского во многом объединяют этот и предыдущий подходы), представленную в школах К. Ф. Тарановского, В. Н. Топорова и др.; постструктуралистскую, восходящую к идеям Ролана Барта и Юлии Кристевой (методология Майкла Риффатерра и Жерара Женетта, в свою очередь, нейтрализует этот и предыдущий подходы). Что-то попадает в кругозор исследователя как «своя», разделяемая программа, что-то - как «чужая», отрицаемая, что-то может вообще не замечаться. Между тем именно и только одновременный и полный учет теоретической рефлексии в области межтекстовых взаимодействий может приблизить к пониманию всей сложности обсуждаемой исследовательской области, и спустя полвека не перестающей вызывать вопросы. Скажем, почему в утверждении неоригинальности, вторичности, традиционности вновь создаваемого текста сошлись предельно - в кавычках или без кавычек - левые Р. Барт и Ю. Кристева и - в кавычках или без кавычек - довольно правые Т. С. Элиот, Э. Р. Курциус, о. Павел Флоренский (в своих искусствоведческих работах, mutatis mutandis применимых и к словесным текстам)? Ясно, что их объединило отрицание романтического индивидуализма, культа неповторимости, личной гениальности - но как и почему?

По многим теоретическим вопросам участникам состоявшегося семинара не удалось выработать общей платформы. Но можно отважиться на предположение о возможном направлении дальнейшего поиска. Он состоит в сближении, условно говоря, «исторического» и «теоретического» подходов. Первый настаивает на дробности наблюдаемой нами «истории интертекстуальности»: межтекстовые отношения представляются совершенно различными применительно к разным эпохам, к разным жанрам и традициям, к творчеству разных авторов, к разным уровням и режимам текста. Второй ищет если не общих ответов, то хотя бы общих критериев. Перифразируя великого лингвиста, можно сказать, что выявлению 
подлежат не столько «принципы», общие для всех случаев - ихто, возможно, и не существует - сколько «параметры» (общие для всех случаев вопросы, ответы на которые будут различными, но соотносимыми, результатами «по одной шкале»). Если теоретический подход будет способен учесть историческую дробность материала, а исторический допустит возможность выработки общих параметров описания, позиции могут быть существенно и плодотворно сближены.

По итогам прошедшего семинара планируется издание коллективной монографии, посвященной проблематике межтекстовых взаимодействий в теоретической и исторической перспективе. 